\title{
EL CAMINO DE LA MINA, VEHÍCULO DE EMOCIONES EN CALDERÓN
}

ENRIQUE RULL

UNED. Madrid

\section{VALOR Y FUNCIÓN DE LA MINA EN CALDERÓN}

Los caminos tortuosos, los espacios oscuros, los laberintos, las cavernas, las tenebrosas grutas, y otros lugares naturales o artificiales de carácter sombrío, tienen lugar en el ámbito con el que Calderón construye a menudo sus comedias. Recordemos a título de ejemplo paradigmático los lugares en los que yacen encerrados Segismundo, Narciso o Semíramis'. Evidentemente se trata de construir o diseñar para la escena espacios en los que el claroscuro, el contraste, las luces y sombras delimiten unos ámbitos específicos en los que el sentir barroco halle una expresión acorde con las imágenes figurativas que igualmente diseñaron en la pintura el tenebrismo de Caravaggio, o el barroco de los españoles Velázquez, Ribera y Zurbarán, o la profundidad del claroscuro de Rembrandt, entre tantos otros. En cualquier caso la tendencia de la época a sumergirse en un mundo moral que revelase la cara oscura del mundo o del hombre, por contraste con la luminosidad de la alegría, de la vida y del bien, es perceptible en cualquier espíritu de la época, sea pintor, como Rubens, o poeta como Góngora o Quevedo, o dramaturgo como Calderón. El espíritu del tiempo era proclive a imágenes contrastadas de bien y mal, de luz y oscuridad, de nacimiento y muerte (la cuna y la sepultura será tema predilecto de Quevedo, pero también de Gracián y Calderón). Generalmente, y una vez asentado esto, que no por ser común es menos interesante destacar aquí para nuestro propósito, estos ámbitos revelaban o se expresaban en obras

\footnotetext{
${ }^{1}$ Sobre este tema ya existen algunos estudios interesantes, como el de M.S. MAURIN («The monster, the sepulcre and the dark: Related patterns of imagery in La vida es sueño», in Comedias de Calderón (Edición facsímil), T. XIX, London, Tamesis Books, 1973, pp. 133-149). Para el valor de símbolos como la «torre» y otros lugares tenebrosos vid. también A.L. Cilveti, El significado de La vida es sueño, Valencia, Albatros, 1971, pp. 185-202.
}

Rlit, LXIV, 128 (2002), 385-411 
de tema grave, con contenido moral ascético, que estaban circunscritos a lugares de reposo, nacimiento o prisión (recordemos la gruta o torre de Segismundo, de nuevo) y, por tanto, se referían a algo estático.

La mina, por el contrario, es un camino por el que transitar, y aunque a veces se relaciona con todo lo anterior, existen algunos matices de diferencia, que son los que nos proponemos aquí dilucidar ${ }^{2}$. En primer lugar, lo que distingue la mina de la caverna es su aspecto dinámico y como tal creador. Por eso, subsidiariamente, y aunque el ámbito específico de la mina se puede encontrar en obras de diverso género teatral, en las obras que posee un valor más inmediato, esencial y peculiar es en las que se utiliza como recurso de acción, no como lugar de reposo, prisión o permanencia accidental. En segundo lugar, si bien es cierto que las referencias a este ámbito de la mina en la obra de Calderón son múltiples, las obras de las que nos vamos a ocupar, siquiera sea brevemente, pertenecen por lo menos a cuatro categorías: comedias bélicas, religiosas, mitológicas y de capa y espada. Podemos, afinando más aún, reducir éstas, a tenor de la funcionalidad de la mina en ellas, y al sentido mismo de su significado ambivalente (como galería que se construye para colocar explosivos, y como mera excavación subterránea), a dos categorías: una, la que se refiere al valor que posee la mina como vehículo de estrategia militar, y la otra, la que la mina tiene como vehículo de acción misteriosa, de confusión y de sorpresa. Mientras que la primera forma suele ser ocasional en el desarrollo del argumento mismo de la obra, aunque su importancia pueda ser determinante para su desenlace, la segunda es propiamente la función eminentemente teatral a la que sirve el motivo de manera constante y eficiente: la creación de una esencial aventura, en la que la emoción de lo inesperado es el fundamento mismo de su idea.

Así, al casi centenar de citas que se pueden recoger en las comedias calderonianas ${ }^{3}$ del término «mina», las que son verdaderamente relevantes, por una razón u otra, se refieren a las obras siguientes: Amar después de la muerte o El Tuzaní de la Alpujarra, Apolo y Climene, La aurora en Copacabana, El encanto sin encanto, El galán fantasma, Mujer, llora y vencerás, Origen, pérdida y restauración de la Virgen del Sagrario, La banda y la flor, y alguna más en menor medida ${ }^{4}$. Referiremos la función

\footnotetext{
${ }^{2}$ Sobre la función de la mina en El galán fantasma de Calderón, ya dimos noticia en nuestra edición de esta obra (Madrid, SGEL, 1983, pp. 33 y ss.).

${ }^{3}$ Según el TESO (CD ROM, publicado por Chadwick and Healey), deberán añadirse algunas más ausentes en él por efecto de la transcripción de las ediciones manejadas, no siempre las mejores; y algunas menos, por el efecto de duplicar títulos que corresponden a una sola obra, como por ejemplo Amar después de la muerte y El Tuzaní de la Alpujarra. A esto hay que añadir que la búsqueda del término no puede reducirse al término «mina», sino a todos sus derivados y a algunos sinónimos.

${ }^{4}$ Por ejemplo, A secreto agravio, secreta venganza, Agradecer y no amar, Para vencer amor, querer vencerle, Primero soy yo, La púrpura de la rosa, entre otras varias. De las que no cita el TESO hay que destacar La aurora en Copacabana.
} 
del motivo en algunas de ellas y nos centraremos en el análisis más pormenorizado de las que son fundamentales a nuestro propósito, que fue sin duda también el de Calderón.

\section{MiNAS CON CARÁCTER ESPECÍFICAMENTE BÉLICO Y RELIGIOSO}

En primer lugar consideraremos las que se refieren a la mina con un carácter específicamente bélico. Por ejemplo, en Amar después de la muerte, que, aunque versa sobre una historia de amor, tiene como fondo histórico el levantamiento morisco de las Alpujarras, se nos expone la toma de la villa de Galera, para lo cual el soldado español Garcés, por el que el autor no parece sentir simpatía precisamente, organiza la conquista mediante la explosión de una mina, lo que se explica en estos términos:

$$
\begin{aligned}
& \text { Esta de la mina es } \\
& \text { la boca que al muro sale: } \\
& \text { llegad, llegad con silencio } \\
& \text { pues no nos ha visto nadie. } \\
& \text { Ya está dada fuego, y ya } \\
& \text { esperamos por instantes } \\
& \text { que reviente el monte, dando } \\
& \text { nubes de polvo al aire. } \\
& \text { En volándose la mina, } \\
& \text { ninguno un minuto aguarde, } \\
& \text { sino ir a ocupar el puesto } \\
& \text { que ella nos desocupare, } \\
& \text { procurando mantenerle } \\
& \text { hasta llegar lo restante } \\
& \text { de la gente que emboscada } \\
& \text { en esta espesura yace. }
\end{aligned}
$$

Explota la mina y Don Alvaro Tuzaní, el protagonista, describe así sus efectos y su decisión de salvar a su amada Maleca por encima de todo:

$$
\begin{aligned}
& \text { En confusos laberintos } \\
& \text { de armas ya la villa arde, } \\
& \text { y para abortar horrores, } \\
& \text { víbora de alquitrán y áspid } \\
& \text { de pólvora, hecha pedazos, } \\
& \text { todas las entrañas abre. } \\
& \text { Estrago de España es éste. } \\
& \text { Ni soy noble, pues, ni amante } \\
& \text { si a socorrer a mi dama } \\
& \text { al fuego no me arrojare, } \\
& \text { trepando al muro y rompiendo } \\
& \text { sus almenas de diamante; } \\
& \text { que como yo entre mis brazos }
\end{aligned}
$$




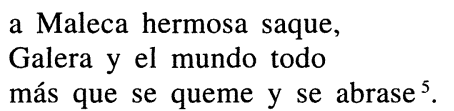

Aunque sepamos que en definitiva no consiga sus propósitos de salvamento, llegando a ser el propio Garcés el asesino de Maleca, y aunque Alvaro al final tome cumplida venganza del crimen en la persona de su ejecutor. Verdadera tragedia bélica y amorosa a un tiempo, se distingue de otras obras en las que el motivo de la mina tiene un papel bélico en que ésta pertenece más al género trágico que a la comedia propiamente dicha ${ }^{6}$.

En otra dimensión igualmente ambivalente se mueven las comedias religiosas, pero de apariencia guerrera, como son La aurora en Copacabana y La Virgen del Sagrario. Ambas relatan historias de tema mariano. En la primera se nos habla de la feroz guerra entre los españoles Pizarro, Almagro y Candía con los idólatras indios; uno de los más rebeldes, Tucapel, proyecta y consigue destruir con una mina el palacio de Cuzco. Dice así el inca:

$$
\begin{aligned}
& \text { Los más principales cabos } \\
& \text { desa española canalla } \\
& \text { con los más soldados suyos } \\
& \text { se alojan en ese alcázar } \\
& \text { de los Ingas; éste tiene } \\
& \text { al reparo de las aguas } \\
& \text { que suelen de la ciudad } \\
& \text { inundar calles y plazas, } \\
& \text { entre otras muchas surtidas, } \\
& \text { una mina que desagua } \\
& \text { cerca de aquí, cuya boca } \\
& \text { es preciso que ignorada } \\
& \text { de hombres tan recién venidos } \\
& \text { esté a estas horas sin guardas, } \\
& \text { y si por ella eligiendo } \\
& \text { el cabo de mayor fama, } \\
& \text { hicieses que con la gente } \\
& \text { también de más importancia } \\
& \text { la mina entrase llevando } \\
& \text { seca fajina a la espalda } \\
& \text { y oculto fuego, no dudes } \\
& \text { que si por el pie la llama }
\end{aligned}
$$

\footnotetext{
${ }^{5}$ Amar después de la muerte y el Tuzaní de la Alpujarra, en Obras completas de Calderón, ed. de A. Valbuena Briones, Madrid, Aguilar, 1959, Tomo I, pp. 343 b y 344 a.

6 Vid. sobre esta obra los estudios de J. Alcalá-Zamora, «Individuo e Historia en la estructura teatral de El Tuzaní de la Alpujarra» en Actas del Congreso Internacional sobre Calderón y el Teatro Español del Siglo de Oro (Madrid, CSIC, 1983, tomo I, pp. 343-363). También «El problema morisco bajo Felipe II, en la reflexión y crítica de Calderón», capítulo de los Estudios calderonianos de este autor (Madrid, Real Academia de la Historia, 2000).
} 
prende una vez, vuele todo, pues su arquitectura rara toda es preciosas maderas ${ }^{7}$.

La consecución de este proyecto se realiza igualmente de la manera que sigue:

\begin{tabular}{|c|c|}
\hline & ¡Fuego, fuego! \\
\hline PIZARRO & $\begin{array}{l}\text { Mas ¿Quién en confusión tanta } \\
\text { ciudad y palacio pone? }\end{array}$ \\
\hline & $\begin{array}{l}\text { Iré a ver de qué se causa. } \\
\text { (Sale Candía.) }\end{array}$ \\
\hline CANDÍA & $\begin{array}{l}\text { ¿De qué ha de causarse, si es } \\
\text { un volcán todo el alcázar, } \\
\text { que del centro de la tierra } \\
\text { humo aborta y fuego exhala? }\end{array}$ \\
\hline & $\begin{array}{l}\text { De sus bóvedas empieza, } \\
\text { y es que, sin duda, minadas } \\
\text { los bárbaros las tenían. }\end{array}$ \\
\hline 2RO & Acudamos a atajarlas ${ }^{8}$ \\
\hline
\end{tabular}

Ante el peligro, los españoles invocan a la Virgen, quien en forma de la imagen de Nuestra Señora de Copacabana, se les aparece en una nube y deja caer ùna nieve salvadora sobre el fuego. Después de otros muchos avatares la obra concluye con la conversión de los indios del Perú al cristianismo.

En Origen, pérdida y restauración de la Virgen del Sagrario tenemos una realización motívica muy semejante. En la primera jornada se nos habla de la leyenda acerca de la fundación de la cueva de Hércules atribuida a Recesvinto en el siglo viI, cueva que permanecería cerrada a todos sus sucesores para que no ocurrieran terribles desgracias ; por romper el juramento y abrir años después Don Rodrigo la cueva sellada tendría lugar la invasión de los moros. Tiempo más tarde (ya en la jornada segunda) Godmán, alcaide toledano, confía a los caballeros Teodosio, Iñigo y Rodrigo el secreto que rodea a la imagen de la Virgen, que guarda celosamente en el templo ante el avance de los moros sobre Toledo. El secreto es su ocultamiento para que no caiga en manos del enemigo, como se describe así:

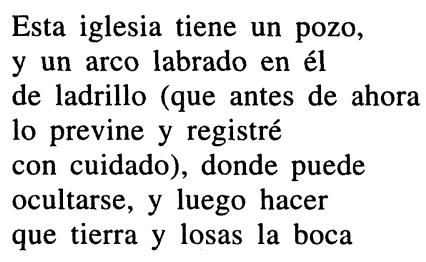

${ }^{7}$ La aurora en Copacabana, ed. cit. de Valbuena Briones, p. 1380 a.

${ }^{8}$ Ibíd., p. 1381 a y b. 


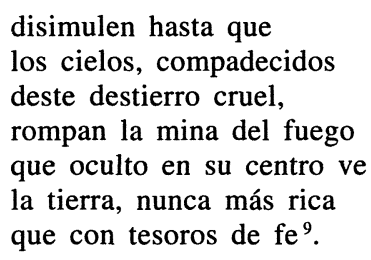

Siglos después, ya en la jornada tercera de la obra se oye una música que canta:

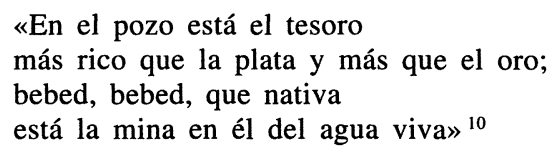

que induce a pensar al arzobispo Don Bernardo (el santo de origen francés que sería arzobispo de Toledo y protegido por Doña Constanza, esposa de Alfonso VI) que hay algún misterio en la letra de la canción. Por ello, la misma Reina Constanza, con una azada cava la tierra hasta encontrar la mina, y dice al Rey:

$$
\begin{aligned}
& \text { Llega a esa profunda boca } \\
& \text { y verás que cuando llegas, } \\
& \text { en ondas de luz te anegas: } \\
& \text { sus santos umbrales toca, } \\
& \text { y verás que te provoca } \\
& \text { un temor que el alma lleva... } \\
& \text { Una voz que dulce eleva, } \\
& \text { y permíteme tener } \\
& \text { vida, hasta llegar a ver } \\
& \text { el prodigio de esta cueva }{ }^{11} \text {. }
\end{aligned}
$$

El rey la hace levantar del suelo, y el moro Selim se ofrece a bajar él a la cueva, donde descubrirá deslumbrado la mina donde encuentra la imagen:

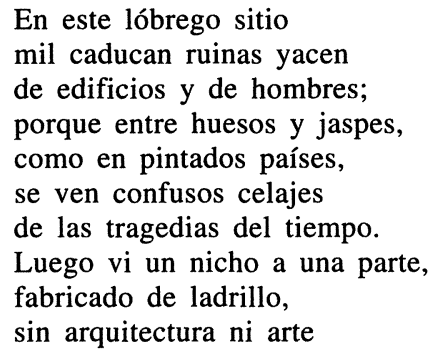

\footnotetext{
${ }^{9}$ La virgen del sagrario, ibid, p. 269.

${ }_{10}$ Ibíd., pp. 275 y ss.

$"$ Ibíd., p. 277 b.
} 
mejor, que a efecto no más

de ocultar tesoros grandes.

Llegué con la luz a él,

y bien pudiera excusarme

de la luz, porque bastaba

la que los ojos esparcen

de una divina Señora... ${ }^{12}$

Aunque en la obra el motivo de la mina procede de una leyenda relacionada con la historia desde la guerra contra los moros, el carácter eminentemente de misterio, en este caso religioso, que depara su descubrimiento separa la obra de la función eminentemente bélica que tenía en las anteriormente mencionadas.

\section{LA MINA, CAMINO GUERRERO Y ÁMBIVALENCIA AMOROSA}

Finalmente, dentro de esta misma sección en la que la mina se utiliza como medio guerrero, pero ya ligado a una cierta ambivalencia amorosa, podríamos considerar la comedia cortesana o palaciega, Mujer, llora y vencerás.

La comedia a que nos referimos pertenece al género aristocrático de la comedia «de fábrica», que se distingue de la comedia de capa y espada por ser ésta última una comedia esencialmente urbana o «de personas particulares», como diría el poeta, dramaturgo y preceptista Bances Candamo ${ }^{13}$, discípulo del propio Calderón, pero que desde la perspectiva de la técnica argumental coincide con ella en la preponderancia de lo que llamamos el «enredo». Lo que las diferencia es el tono más grave en la comedia referida, como corresponde a una obra de elevado rango social y hecha con seguridad para ser representada en palacio ${ }^{14}$. En este sentido y en el del constante ambiente guerrero (aunque sea para conquistar a una dama, también lo fue Troya, al fin y al cabo) podemos incluirla entre los dramas bélicos referidos.

${ }^{12}$ Ibíd., p. 279 a.

${ }_{13}$ Vid. F. BANCES CANDAMO, Theatro de los theatros de los passados y presentes siglos, ed. de Duncan W. Moir, London, Tamesis Books, 1970, p. 33.

${ }_{14}$ Así consta en C. PÉrez PASTOR, Documentos para la biografía de Don Pedro Calderón de la Barca, Madrid, Fortanet, 1905, pp. 267-268. Se consigna textualmente en el Documento 161: «En Madrid a dos días del mes de Febrero de mil y seiscientos y sesenta... yo el escribano fui a casa de Sebastián de Prado, autor de comedias, a donde vi estar ensayando una comedia que su título, según dixeron, es Muxer, llora y vencerás, de don Pedro Calderón, y la ensayaba el dicho Sebastián de Prado y Juan de la Calle, autores, y su compañía y otras personas de fuera de las compañías, y me dixeron que era una de las tres comedias que Don Pedro Calderón de la Barca había escrito para las tres fiestas de Su Magestad para Domingo, Lunes y Martes de Carnestolendas» (p. 267). 
Dos caballeros Enrique y Federico están enamorados de la misma dama Madama Inés de Turincia, hija del Landgrave de Hassia, por la cual disputan. El parlamento dispuso que uno de los dos fuese su marido, a lo que ella tiene que decidir, y lo hace entre dos hombres muy distintos: uno, Federico es sabio y dado al estudio; el otro, Enrique, valiente y guerrero. El primero, según ella, la adora, el segundo la aborrece (lo que por otra parte no es cierto). En esta situación Inés recurre a una curiosa metáfora para explicar su amor:

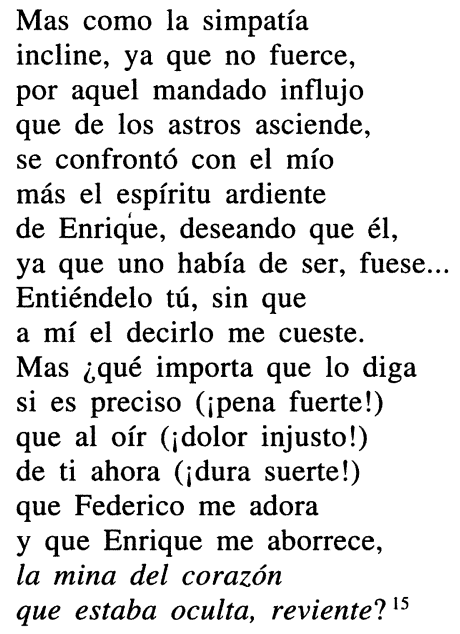

Calderón explica la forma específica del amor de Inés con la imagen subterránea (por estar oculto) y bélica (por el fuego de la pasión) de la mina, que será una especie de curiosa premonición psicológica de la mina verdadera que surgirá más tarde, camino oculto de sorpresas inesperadas. Una original y creativa imagen, anticipadora en este caso, que parece mucho menos frecuente que el tópico volcán, Etna, Mongibelo, etc., utilizado en la mayor parte de sus comedias.

Mientras el desacuerdo de los hermanos mantiene la decisión de elegir en Inés, se organizan fiestas y bailes. Curiosamente describe uno de estos el gracioso Patín de la siguiente manera:

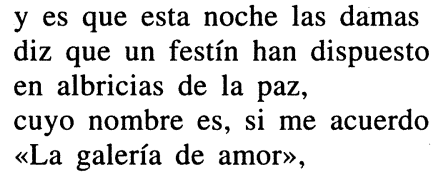

${ }^{15}$ Mujer, llora y vencerás, ed. cit. de Valbuena Briones, tomo II, p. 1424 b. El subrayado es nuestro. 
que es un bailete compuesto
de cuantos en el salón de cuantos en el salón

Es cierto que «la galería de amor» recuerda también un tanto a la esperada mina conductora, pues juega quizá con el ambivalente sentido de «galería», como corredor de palacio o de fortificación. Por eso tiene claro interés el nombre del baile. Que por cierto es cantado «en forma de sarao» de la manera siguiente:

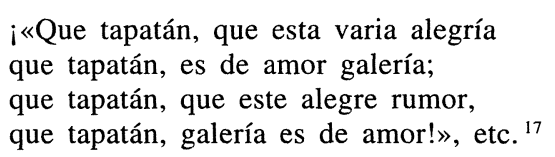

E Inés que prefiere claramente a Enrique, pero que no se decide a demostrarlo no parezca liviandad, se decide en el baile cuando tropieza y cae en brazos de él. Esto es suficiente para proclamarle Duque ante sus vasallos. Aquí parecería acabar la obra si no fuera porque Federico se dispone a preparar un ejército para regresar y desquitarse de lo que él cree una ofensa de su hermano, quien le vio llorar por el amor de Inés y disponerse a abandonar su patria. Inés y Enrique se aprestan a defenderse, pero viéndose perdidos huyen por una mina que hay en la torre, resto de un antiguo fortín. Mas Enrique no lo hace a tiempo y es apresado por Federico. Madama Inés al saberlo se enfrenta a Federico, pero éste se lleva prisionero a su propio hermano, mientras continúa la batalla. Inés, en compañía de su dama Laura, al ver a los suyos derrotados y desmandados, exclama:

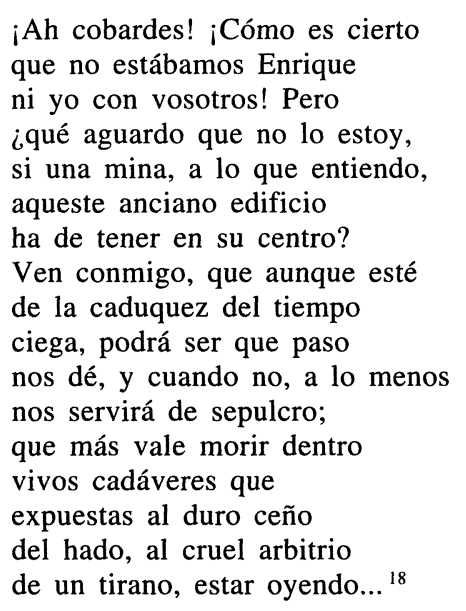

${ }^{16}$ Op. cit., p. 1429 a

17 Ibíd., p. 1433 a.

18 Ibíd., p. 1433 b. 
Cuando llega victorioso Federico, un soldado le advierte que han descubierto una mina por donde Madama ha huido. Desesperado Federico de no poder alcanzar su amor decide entregar la ciudad a saco. Y aunque se corre la voz de que Inés se ha arrojado desde una almena al Rin, Enrique yace desesperado y yerto, Federico no se conmueve ni retracta de su decisión, hasta que la propia Inés regresa y le reta ella misma a duelo personal, al ver que todo está en poder de su adversario: su esposo, su Estado, el principado de Turincia, etc. Al final no puede disimular su llanto, que es lo que conmueve a Federico, quien decide tener, ya que no puede otra cosa, la grandeza noble de hacer felices a todos los demás.

En esta comedia, sólo bélica en la apariencia, tiene sin embargo un cierto juego la mina como símbolo y metáfora del amor y de alegría, también de huida y de refugio, de camino de ida y de vuelta. Calderón juega hábilmente con su polivalencia, como vemos en los textos citados, lo que significa un enriquecimiento del concepto, que aunque no es excesivamente relevante desde el punto de vista argumental, no hay duda que estructura la acción convenientemente y con habilidad. En otros textos veremos la mucha mayor relevancia del motivo. Aquí se mueve en el terreno de la ambigüedad amorosa y bélica, lo cual es muy apropiado para la clase de comedia «de fábrica» que realiza. Y supone un escalón intermedio entre los dramas bélicos señalados al comienzo y las comedias propiamente de enredo que veremos a continuación.

\section{LA MINA METÁFORA EXCLUSIVA DE LA PASIÓN AMOROSA}

Hay otras comedias en las que se utiliza la mina como valor metafórico amoroso exclusivamente. Ocurre, entre otras, en La banda y la flor. En esta extraña comedia, por lo inhabitual del cuádruple galanteo amoroso de Enrique, el protagonista, a Lísida, Clori, Nise y Celia, aunque sea motivado ese galanteo por causas bien distintas, se recurre a esa metáfora en varios momentos, ya sea para expresar la pasión incontenible del personaje principal, ya sea para indicar la que despierta en otros pechos:

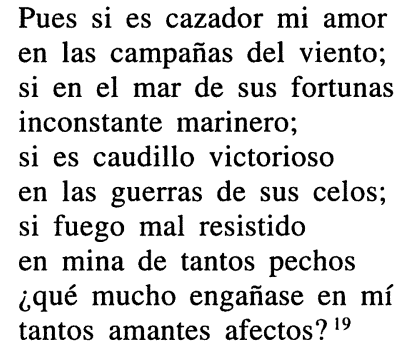

${ }^{19}$ La banda y la flor, ibíd., p. 434, a. 
Esto ocurre cuando el Duque de Florencia, enamorado de Clori, antigua amante de Enrique, propone a éste que conquiste a Nise, prima de Clori, para averiguar los sentimientos de su amada, y lo hace de esta manera:

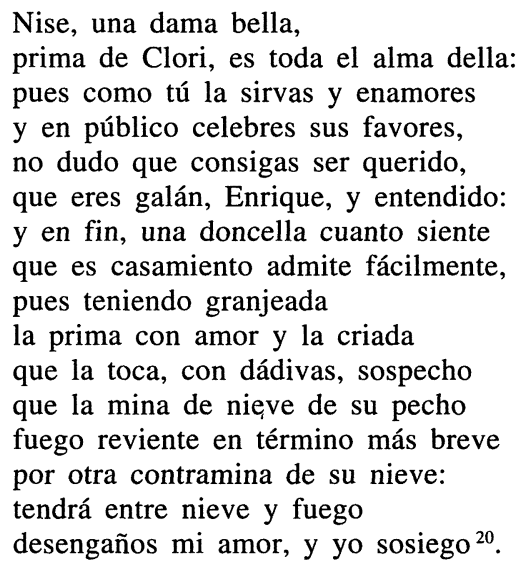

Enrique, un verdadero conquistador, aunque lo sea por la fuerza de las circunstancias, hará lo que el Duque le manda con las inesperadas consecuencias que le proporciona tan complicado asunto. Y de esta manera, mientras le oyen escondidas su antigua amante Clori y su verdadera amada Lísida, se declara falsamente (o no tanto) a Nise, como le había recomendado el Duque, para que a través de ésta pueda aquél llegar al corazón de Clori, y lo hace reflexionando así:

$$
\begin{aligned}
& \text { (iAy Dios! Sola Nise está, } \\
& \text { nadie me mira, bien puedo } \\
& \text { perderle a mi amor el miedo, } \\
& \text { y empezar a romper ya } \\
& \text { la mina del Duque. Va } \\
& \text { de amor fingido y secreto. } \\
& \text { Buen efecto me prometo, } \\
& \text { pues solo y seguro estoy } \\
& \text { de mi Lísida: que hoy } \\
& \text { no hay que temer en efeto) }{ }^{21} \text {. }
\end{aligned}
$$

El desenlace de tanto enredo puede sorprender, y de hecho a Valbuena Briones le parece «insólito» y que demuestra el sofista que había en Calderón ${ }^{22}$, pues al final de la obra, el Duque hace casar a Enrique con Lísida y él, para vengarse de Clori, renuncia a ella. Yo no creo que sea tan extraño este final. Quizá no es el típico desenlace de emparejamientos per-

\footnotetext{
${ }^{20}$ Ibíd., 437, a.

${ }^{21}$ Ibíd., 442, b.

${ }^{22}$ Ibíd., 420 a y b.
} 
fectos y generales de otras infinitas comedias de la época, pero se aviene con facilidad a los criterios calderonianos de la renuncia del príncipe a su gusto por causas éticas, quizá, es verdad, más propio de los dramas que de las comedias. Sí, hay que reconocer que el triunfo de Enrique es un poco cínico, pues alcanza su gusto, después de solicitar y despertar tantas pasiones, pero lo hace siendo en el fondo fiel a su amada auténtica, mientras que la renuncia del Duque es un castigo y a la vez un escrúpulo, por saber que ella es la enamorada de Enrique. Sin embargo, lo que nos ha llamado profundamente la atención de esta comedia no son sus peculiaridades, indudablemente relevantes, sino el exclusivo tratamiento metafórico que se hace del concepto de la mina, que nunca aparece como objeto real. Es otra variante de la idea que se insinuaba en Mujer, llora y vencerás (allí combinado el elemento metafórico con el real) y que aquí se hace elemento figurado y único.

\section{LA MINA COMO LABERINTO DE AMOR Y SENDERO DE ÉXTASIS}

En el grupo de obras que se circunscriben a la utilización del recurso de la mina como puro elemento laberíntico de enredo, debemos situar principalmente dos: El encanto sin encanto, y El galán fantasma. Formarían parte de lo que Valbuena Briones llama «trilogía de los amantes misteriosos», junto con La dama duende ${ }^{23}$, aunque creo que se trata más bien de una tetralogía, si tenemos en cuenta también la comedia mitológica Ni amor se libra de amor. En la primera, El encanto sin encanto ${ }^{24}$, el recurso de la mina es un elemento más del enredo esencial, los otros son la torre y el torno. La obra tiene cierta conexión con Amar por señas de Tirso de Molina, pero es mucho más movida y multiplica lo elementos de ocultamiento, que en Tirso era un simple torno, por los tres mencionados. Igualmente la técnica de ocultamiento de la dama recuerda la famosa comedia propia La dama duende, que irónicamente se cita en nuestro texto. La acción se desarrolla en un lugar inhabitual, Marsella, adonde arriba un español, Enrique, quien tras salvar a una dama de perecer ahogada tras hundirse su góndola, de nombre Serafina, se ve envuelto en mil enredos hasta parar en una torre desde donde la dama le habla en la oscuridad y tras un torno. Es Serafina que se ha ingeniado esto para no revelar directamente su amor por el caballero español. Las referencias a la mina provienen de ella misma que la conoce, y por la que piensa que Enrique pueda huir hasta el mar, pues es perseguido por haber herido a otro caballero, adonde desemboca la misma:

${ }^{23}$ Vid. la «Nota preliminar» a su edición citada de Obras completas, II, p. 633.

${ }^{24}$ El encanto sin encanto, ibíd., pp. 1575-1616. 


$\begin{array}{ll}\text { FABIO } & \text { Vengo en que en ese secreto } \\ & \text { no den; ¿si por las almenas } \\ \text { entrasen al torreón? } & \text { Valdrémonos de las ciegas } \\ \text { SERAFINA } & \text { minas, haciendo que una } \\ & \text { que sale a la orilla desa } \\ \text { ría que va al mar, se aclare, } & \text { y teniendo un barco en ella } \\ & \text { siempre aprestado, y la boca } \\ & \text { hasta este trance cubierta } \\ \text { de tierra y broza, podrá } & \\ \text { huir en él } & \end{array}$

Más adelante la dama insistirá al viejo Fabio:

$$
\begin{aligned}
& \quad \text { Al punto, Fabio, } \\
& \text { id y traed dos vestidos } \\
& \text { a nuestra moda, porque } \\
& \text { vayan más desconocidos. } \\
& \text { Prevenid la mina y barco, } \\
& \text { y, pues ya habiendo rompido } \\
& \text { el día, no es ocasión, } \\
& \text { en habiendo anochecido } \\
& \text { entrad por ella y llevadle } \\
& \text { por la ría hasta el navío } \\
& \text { que llegó esta tarde al puerto }{ }^{26} \text {. }
\end{aligned}
$$

No mucha mayor función tiene el dicho motivo, porque además el protagonista no tendrá que huir, ya que es escondido en la torre por la dama que conseguirá su propósito amoroso casando al final con él. La originalidad de la comedia radica en el encantador ambiente marítimo de la primera jornada, la alegría carnavalesca de las fiestas y el misterio de los lugares secretos de las dos jornadas restantes. Importante nos parece la utilización específica de la mina, que da por esta vez al mar, ampliando así las posibilidades del camino, lógicamente terrestre pero liberador en este caso al posible embarco en una nave que podría esperar al protagonista. La mina que desemboca en el mar es así signo de liberación, más que de encierro, signo de salida del laberinto más que camino por él. La contagiosa alegría del mar que se nos ha descrito al principio y que podía haber sido la causa de la desgracia de Serafina, se torna afortunadamente en posible salvación de Enrique, aunque esta salvación, sólo que más calurosa y honda, la halla en los brazos de su amada.

La segunda comedia de este pequeño ciclo que vamos a analizar es $E l$ galán fantasma. Se trata de una de las comedias suficientemente conoci-

${ }^{25}$ Ibíd., p. 1590 a.

${ }^{26}$ Ibid., p. 1603 b. 
das, editadas y representadas de entre las «de enredo» de su autor ${ }^{27}$, aunque algo menos, por ejemplo, que La dama duende, No hay burlas con el amor o Casa con dos puertas. En esta obra el motivo de la mina es crucial. No es ya una anécdota, una metáfora o un hecho aislado. Por vez primera su utilización es constitutiva, argumental y extensamente, de una realidad sustancial como medio de comunicarse dos amantes (Julia y Astolfo) cuyas relaciones imposibilita el Duque de Sajonia, quien celoso de Astolfo al saber que Julia le quiere, intenta vengarse de él buscándole para matarle. Julia avisa a su amado para que no se acerque a su casa. Pero como para los amantes no hay obstáculos, gracias a su amigo Carlos tendrá conocimiento de una mina (construida hace tiempo, y no precisamente con propósitos conciliadores, para vengar un agravio contra el padre de Julia), que ahora le servirá para ponerse en contacto secreto con ella, pues como él mismo dice:

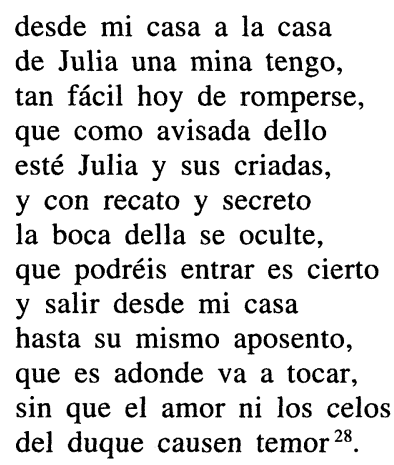

En un posterior enfrentamiento que tiene Astolfo con el duque es herido por éste y dado por muerto. A partir de aquí la acción transcurre en una acumulación de motivos por medio de los cuales una cierta vida fantasmal del protagonista se va realizando en ámbitos nocturnales y tenebrosos: el subterráneo de la mina, los jardines por la noche, su ocultamiento tras las puertas, en determinadas habitaciones, etc. que va creando un clima romántico intensificado además por sus amores imposibles y su enterramiento fingido, como ya estudiamos en otro lugar ${ }^{29}$.

\footnotetext{
${ }^{27}$ La editamos nosotros con estudio preliminar (Madrid, SGEL, 1983 ); igualmente J. Romera Castillo (Barcelona, Plaza-Janés, 1984). Fue representada espléndidamente por José Luis Alonso en el Teatro Español de Madrid en 1981, coincidiendo con la celebración del tercer centenario de la muerte del dramaturgo.

${ }^{28}$ El galán fantasma, ed. de Enrique Rull, op. cit., p. 207, vv. 533-545. Para la comprensión de la misma y sus valores específicos dentro del género, recomendamos la lectura del Estudio Preliminar de esta edición. Editamos la obra junto a El alcalde de Zalamea.

${ }^{29}$ Ibid., p. 41.
} 
A esto hay que añadir escenas un tanto espectaculares y sorprendentes, como en la primera aparición de Astolfo después de «muerto», cuando a través de la mina llega, lleno de tierra, rompiendo la salida ante los ojos asombrados de Julia y el gracioso Candil, lo que provoca el desmayo de ella y la alarma consiguiente de éste:

\begin{tabular}{|c|c|}
\hline ASTOLFO & $\begin{array}{l}\text { Julia, } \\
\text { oye, escucha, mira, advierte.... } \\
\text { Sobre las flores cayó. }\end{array}$ \\
\hline & $\begin{array}{l}\text { ¡Oh, que mal hice ( } ¡ \text { ay de mí) } \\
\text { en romper, sin que estuviese } \\
\text { Julia avisada, esta mina! }{ }^{30}\end{array}$ \\
\hline
\end{tabular}

En esta escena, como ha visto muy bien A. Regalado ${ }^{31}$, hay mucho más que una simple anécdota trivial. Hay, como ha visto con profundidad este crítico, una «auténtica potencia metafísica» en la escena, que va del no ser al ser, del auténtico renacer por el amor. Por otra parte, también es cierto que la irrupción de Astolfo se asemeja a un parto, al «trauma del nacimiento», que dirían algunos psicólogos. Y sin llegar tan lejos en el camino de la interpretación psicológica y fuera del mero contexto literario, diríamos que simbólicamente (y más presentándose su aparición tras su ficticia «muerte», pero al fin y al cabo entendida como tal por todos) este surgimiento tiene todos los visos de una «resurrección», y por tanto, su apariencia se reviste de una gravedad significativa que rebasa el marco puro de la intrascendencia.

Astolfo al sentir la llegada de gente, cerrará la salida y se irá. Escondido acechará a Julia y al Duque con la complicidad de su amigo Carlos. Al final, ante la angustia de Julia que quiere saber si realmente vive, aparecerá ante ella y se explicará todo así:

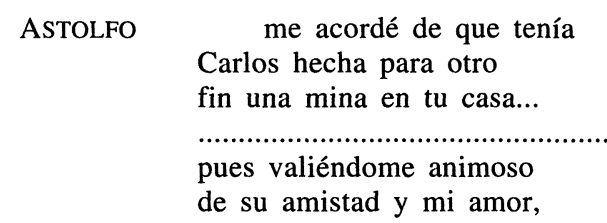

\footnotetext{
30 Ibíd., p. 250, vv. 1511-1513 y 1519-1521.

${ }^{31}$ Vid. lo que, con honda penetración, ha señalado A. Regalado: «Astolfo irrumpe en el teatro desde la 'la ultratumba', de la cueva del no ser, con toda la violencia de un resucitado o de una criatura que quiere volver a nacer, expresión profunda del eterno renacer del amor. El galán fantasma, verdadero tesoro de símbolos, puede abrir el apetito de cualquier psicoanalista, pero sin embargo la reducción psicológica del símbolo de la cueva eliminaría el contexto dramático que dota al lenguaje de significaciones irreducibles al análisis aislado de un enunciado o un discurso y que terminaría castrando la potencia metafísica de la escena» (A. REGALADO, Los orígenes de la modernidad en la España del siglo de Oro, II, Barcelona, Destino, 1995, p. 278).
} 


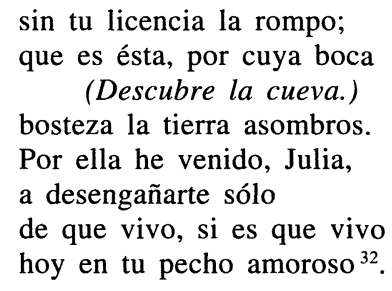

Seguirán los encuentros ocultos de los amantes en un clima ascendente de romanticismo, dadas precisamente las circunstancias. Así, por ejemplo, antes de poder verse en el jardín, de noche, estando anhelante Julia a su espera dialogando con las flores y las estrellas, expondrá sus dudas acerca de si su amado podrá oír su muda seña, a lo que éste, después de haber salido de la mina, contestará:

\begin{tabular}{|c|c|}
\hline ASTOLFO & \begin{tabular}{l}
\multicolumn{1}{c}{ Sí, } \\
que yo respondo por ellas; \\
que puesto que las debí \\
a estas flores alma y voz, \\
bien, hermoso serafín \\
destos jardines, por ellas \\
podré hablar, podré sentir.
\end{tabular} \\
\hline JULIA & $\begin{array}{l}\text { ¡Oh, nunca, señor! ¡Oh, nunca } \\
\text { las cortinas de carmín } \\
\text { corriera la aurora al sol } \\
\text { del pabellón de zafir, } \\
\text { porque nunca hubiera día! } \\
\text { ¡Fuera noche para mí } \\
\text { todo el año, pues las sombras } \\
\text { son mi estación más feliz! }\end{array}$ \\
\hline
\end{tabular}

Cuando inesperadamente llega gente, y la propia Julia le aconseja que se arroje a la mina. Astolfo no quiere dejarla y por fin deciden ocultarse ambos hasta ver qué sucede. En la confusión del momento cae el gracioso Candil a la mina, y el Duque, que llegaba con los demás, pide una luz para ver qué ocurre. Astolfo y Julia deciden entrar por la boca de la mina y escapar, cerrando la salida. Astolfo y Julia llegan a la casa de Carlos, que siempre los protege. Aquí se plantea un dilema, paralelo al amoroso: el del valor de la amistad puesta a prueba, pues Carlos, enamorado de Laura, tiene que decidir entre entregar al Duque a Julia, a quien demanda aquél, o a Laura, a la que han raptado cubriendo su cabeza y habiéndola tomado por Julia; es decir, el dilema es entregar a la amada de su amigo, la verdadera Julia, o a la suya propia, Laura, la falsa Julia. Lo mismo que la prueba del amor llega a sacrificios y generosidad, a riesgos y desafíos, por alcanzar su triun-

${ }^{32}$ Ibíd., p. 264, vv. 1896-1898 y 1901-1909. La acotación en ed. cit. de Valbuena Briones: «Descubre la mina».

${ }^{33}$ Ibid., p. 291, vv. 2581-2595. 
fo; la de la amistad, para Calderón, más importante en esta obra quizá que la otra (de ahí el extraordinario protagonismo de Carlos, quien está más en la escena que el propio Astolfo), se reviste de una calibrada entrega que es lo que otorga su verdadero premio. Pues Carlos es la prueba de la amistad, lo que arguye éste al Duque para solicitar el perdón de Astolfo. El Duque, finalmente, consciente de la desmesura de su poder y soberbia, decidido ante el ejemplo de constancia, ingenio y valentía de sus adversarios por defender su amor, toma el camino tan calderoniano de «vencerse a sí mismo» y otorgarles el perdón. Asombra que este tipo de comedias pudieran parecer frívolas e inmorales en la centuria ilustrada. Sólo en una visión meramente convencional de la sociedad, en una visión igualmente convencional y pacata de las normas morales, podía sentirse el desafío de estas parejas amorosas como atentatorio contra su orden. La amistad y el amor, ejes de la obra, son principios eternos, mientras que las artimañas, los engaños, los disimulos, los equívocos y las tretas no son sino pobres recursos de los individuos, desprotegidos ante una sociedad opresiva que no permitía una libre expresión de los sentimientos, y a los que tenían que acudir para hacer triunfar los anhelos y la nobleza de sus almas.

La función de la mina en El galán fantasma, como vemos, es el eje en torno al cual se articula toda la acción, el sostén de los dos temas principales, y sobre todo, el verdadero fundamento del juego escénico, que hace inolvidable su realidad sobre todo una vez que se haya visto la obra en una representación afortunada. La mina se convierte aquí en vehículo efectista para las apariciones y desapariciones más insospechadas, algunas de las cuales ya hemos indicado, determina el movimiento de la intriga esencial para crear un ambiente de extraordinario misterio y expectación; da cobertura a los personajes protagonistas contra el peligro, incluso de muerte, y si en su origen fue, tal como se nos cuenta, una mina, especie de «caballo de Troya» creada para matar, por la virtud demiúrgica del poeta, el dramaturgo la transforma, auténtica metamorfosis poética, en verdadero «prodigio», de donde nace un «amor tan portentoso» (vv.2024-2025). El fuego, la oscuridad, la muerte, el odio y la venganza, se convierten cual ave Fénix, en amor, abnegación, amistad, generosidad, perdón y nobleza. Es una camino dinámico y creador, tanto, que va de su origen destructivo y criminal hasta su final de armonía, amor y redención. Ese mensaje es el que desprende la comedia de Calderón. Contra esta moral elevada sólo cabe oponer la moral mezquina que se ampara en la soberbia, la envidia, el rencor y el crimen, es decir la moral de la mediocridad y de los prejuicios, la moral de la oscuridad de la mina para la que fue construida, frente a la moral de las flores y las estrellas que reclaman el éxtasis de Julia y Astolfo. Obra insospechadamente viva y hermosa de cuya riqueza ya dimos cuenta detallada en el estudio que precedía a nuestra edición ${ }^{34}$.

\footnotetext{
${ }^{34}$ Vid. la nota 28.
} 


\section{LA MITOLOGIZACIÓN TRASCENDENTE DE LA MINA}

Apolo y Climene es la obra más compleja quizá de cuantas contemplamos en este recorrido emocionante y hasta cierto punto aventurero. El teatro mitológico de Calderón en su esencia reproduce los esquemas habituales de sus comedias y bien sabido que, a excepción de la débil trama mitológica, no son estas obras muy diferentes de las ambientadas en la época contemporánea del autor. El cierto anacronismo de tipos, actitudes y situaciones es intencionado, y es más fácil encontrar cierta fidelidad a la realidad del pasado en las comedias bíblicas o históricas que en las mitológicas. Los dioses se distinguen de los hombres en el estilo más elevado de sus intervenciones y en el respeto que suscitan en los demás personajes antes que en la descripción y carácter que pueden mostrar ante el espectador.

Por eso en Apolo y Climene vamos a encontrar una historia amorosa en el fondo muy humana y, curiosamente muy paralela a El galán fantas$m a$, salvo en su tono y su desenlace. Pero además es una historia concebida desde una trascendencia no tanto proveniente del tema mitológico como de la perspectiva del fatum humano con que está orientada su dirección y su desenlace. Es una obra complicada en cuanto a las situaciones, la abundancia de personajes y los lances, pero no mucho más que las comedias de enredo, como la que acabamos de analizar. Sin embargo donde se marcan más las diferencias es en la complejidad de sus significaciones, de sus posibles orientaciones. Si la historia es una historia cerrada por provenir de un tema nitológico dado, su realización se abre a múltiples incógnitas sobre la orientación de la vida y de sus pasiones, sin que se nos cierre su explicación a un único valor y sentido. Pero en ella, como veremos, se ha realizado una síntesis de drama, comedia «de fábrica» y fábula mitológica. Es la historia de una ninfa virgen, Climene, dedicada al culto de Diana, pero no voluntariamente, sino que, cual Segismundo en La vida es sueño, ha sido encerrada por su padre, Admeto, quien, siguiendo el adverso horóscopo del mago Fitón, que la hacía madre de Faetón (causa de la desgracia del mundo al abrasar parte de éste con la errada conducción del carro del Sol), para evitar que pueda tener descendencia, decide hacerla sacerdotisa de la casta Diana y guardarla en una gruta entre muros y vigilantes, de forma que no pueda salir de allí y nadie la pueda ver. Por otra parte, esta historia guardará relación con la del dios Apolo, quien por recibir más sacrificios que el propio Júpiter en el templo que le estaba dedicado, fue objeto de las iras del celoso dios, quien le arrebató los poderes divinos y le envió a la tierra, donde conoció a Climene, la sacerdotisa de Diana.

La obra de Calderón se inicia en la primera jornada in medias res, cuando Climene descubre que alguien ha profanado el recinto sagrado pe- 
netrando en él. Ha sido Céfiro a quien Sátiro, el gracioso de la obra, ha descubierto el secreto de una mina que conduce a los jardines:

\begin{tabular}{ll} 
SÁtiRo & \multicolumn{1}{c}{ ¡Oh nunca } \\
& aquesta maldita lengua \\
que en su vida calló cosa, & a Céfiro dicho hubiera \\
destos conductos del agua \\
la oculta mina secreta \\
que va a los jardines! ¡Nunca, \\
como jardinero que era \\
antes de pastor, hubiese \\
cubierto en falso de hiedras \\
la gruta en que dan! 35
\end{tabular}

Ante el escándalo que produce la profạnación, Céfiro tapa la salida de la mina y huye. Mientras tanto, Apolo, como despeñado cae en la boca de la mina, a la salida de la que hay un jardín a dónde llegan Climene y otras damas. Cuando queda ésta sola, llorando su situación se presenta Apolo, ante el que ella, asustada y dispuesta a defenderse, pregunta por su identidad y cómo logró entrar allí. Apolo explica que cayó en una sima y al ver una luz se acercó a ese jardín. Pero Climene pretende disparar con su arco y evitar que huya cortándole el paso. Luchan, y a los gritos de la ninfa llegan las damas Flora, Clicie, Cintia y Lesbia. Pero tanto Flora como Clicie se muestran muy impresionadas con la vista de Apolo, al que sin duda conocían de antes. Llaman a los guardas, mientras Climene dice a Apolo que se vaya. Llega Admeto, quien, ante las quejas de Climene y la protesta de todos, explica el por qué de su prisión, y promete liberarla (ya en el inicio de la segunda jornada) si no quebranta el voto de su castidad. Celebran todos con festejos su liberación. Apolo disfrazado de pastor se introduce en la fiesta, en la que Clicie le reconoce y cree que ella es la causa de su venida, porque todavía le mueve su antiguo amor, por lo que sin dar tiempo a una respuesta le cita por la noche en el jardín. Pero Apolo sabe que sólo le retiene allí la belleza de Climene, por quien ha decidido simular que es un pastor de Admeto.

Climene mientras tanto desea quedarse a solas y así se lo dice a las damas que la acompañan. Y es que en el fondo desea ver de nuevo a Apolo al que espera, como así lo expresa:

$$
\begin{aligned}
& \text { Y supuesto que el decirle } \\
& \text { que si osado al jardín vuelve } \\
& \text { seré yo a la que halle, fue } \\
& \text { decirle que vuelva, deje } \\
& \text { al trance de lo futuro } \\
& \text { resultas de lo presente; }
\end{aligned}
$$

\footnotetext{
${ }^{35}$ Apolo y Climene, en ed. cit. de Valbuena Briones, I, 1959, p. 1867, a.
} 


$$
\begin{aligned}
& \text { y vamos a que ya era } \\
& \text { hora de venir, su hubiese } \\
& \text { de venir. Hacia la mina } \\
& \text { que amor ingeniero tiene } \\
& \text { abierta contra la plaza } \\
& \text { de mis vanas altiveces, } \\
& \text { he de acercarme }{ }^{36} \text {. }
\end{aligned}
$$

Mientras tanto suceden una serie de equívocos que muestran cómo las damas están en conocimiento de la mina, cuando llega a ella Céfiro, quien ama a Flora, y a quien Climene confunde con Apolo. Cuando éste se da cuenta de que puede ser descubierto por Climene, se esconde, mientras ella exclama:

\begin{tabular}{ll} 
CLIMENE & \multicolumn{1}{c}{ Detente, } \\
& loco, atrevido, villano. \\
& Echóse a la mina y fuese. \\
& ¡Ay, ingrata Flora! ¿Tú eras \\
& la alentada, la valiente \\
& y la que más me animaba \\
& a buscarle y darle muerte? \\
& Yo me vengaré de ti. (Vase.) \\
FLORA & Primero que tú te vengues, \\
& huiré de tu furia yo. \\
& Tras él a la mina me eche, \\
& sin que tema despeñarme; \\
& que principales mujeres \\
& como una vez se enamoren, \\
& ¿qué innova el que se despeñen? \\
& Salve, pues, con él la vida ${ }^{37}$.
\end{tabular}

Como con Clicie se planteen equívocos semejantes, Climene queda convencida de que ambas la traicionan. Y mientras Flora huye temerosa de la venganza de Climene, Apolo entra en la mina donde se encuentra con Flora, quien le pide que la proteja, lo cual éste promete:

$\begin{array}{ll}\text { APOLO } & \text { Palabra y mano te doy } \\ \text { de ampararte, ya que quiso } \\ \text { la Fortuna que sea yo } \\ \text { el que repare tu daño; } \\ \text { que más que eso al desengaño } \\ \text { mi ventura le debió } \\ \text { de que esa mina no sea } \\ \text { cómplice para otro amor } \\ \text { que el tuyo. De mi valor } \\ \text { fía, y ven donde no vea } \\ \text { nadie tu persona ni halle } \\ \text { noticias de ti }{ }^{38} \text {. }\end{array}$

\footnotetext{
${ }^{36}$ Ibíd., p. 1885, a

37 Ibíd., p. 1886, a.

${ }^{38}$ Ibíd., p. 1890, a.
} 
Una escena semejante tiene lugar entre Apolo y Clicie, quien descubre a Flora y piensa que ambos la engañan. Mientras tanto Climene, en una caza que han organizado contra un jabalí, cree hallar a éste tras unas ramas que se mueven cerca de la mina donde está oculto Apolo, quien sale de su escondite, $y$, ante las acusaciones que Climene le hace, él se muestra sorprendido ignorando quiénes sean las damas a las que ella se refiere. En esto llega Admeto alarmado de que su hija pueda ser víctima de la fiera. Apolo se oculta entre los otros. Climene, desesperada e insegura, determina revelarle la existencia de la mina, pero sin encontrar «razones con qué explicarse». Entonces Flora declara acusadoramente quién puede saberlo:

FLORA
Mientras que suspensa,
por no decir lo que ha sido,
lo que ha de decirle piensa,
pregúntaselo, señor,
a esa horrible, a esa funesta
contramina; della
sabrás quién es el amante
que de noche sale y entra
en sus jardines, y quién
es la que le dio por señas
ser la primera que encuentre,
a cuya causa se queda
en ellos sola a deshoras ${ }^{39}$.

Céfiro y Sátiro confiesan a su vez cómo vieron a un hombre salir de la mina y mencionar a Climene. Ante lo cual Admeto, después de intentar herir a su hija, decide volverla a la prisión. Pero Apolo se la lleva lanzándose al Erídano. Apolo, en la tercera jornada, lleva en sus brazos a Climene, $\mathrm{y}$, ante la duda de si dejarla o no para salvarse de la persecución de Admeto, aparece el mago del horóscopo fatal, Fitón, quien se encarga de su salvamento guardándola en un peñasco. A la llegada de Admeto, Fitón le deja creer que los fugitivos han muerto ahogados, pero Clicie no se deja engañar pues sabe que Apolo no puede morir. Se convierte el peñasco en un palacio, en donde aparece Climene en un trono, quien al despertar de su desmayo se muestra sorprendida de ver a Apolo y comprender que es más que un hombre:

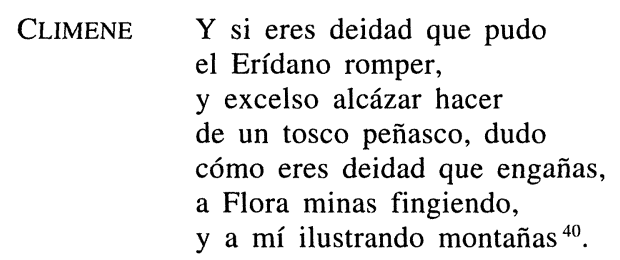

39 Ibíd., p. 1893.

${ }^{40}$ Ibíd., p. 1899 , b y 1900 , a. 
Apolo decide contar toda su historia hasta la caída en la mina:

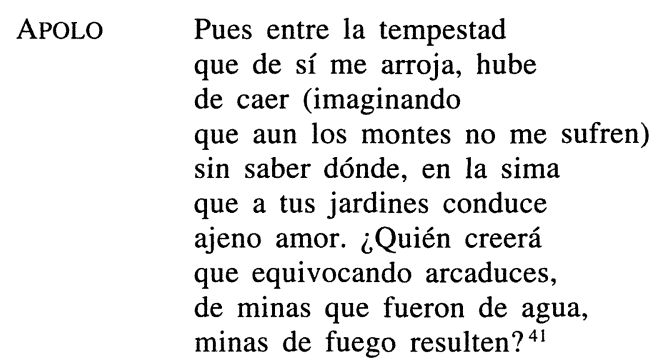

Entonces anuncia Fitón las bodas de Apolo y Climene. Perdonan los dioses a Apolo, pero no a Climene por haber roto el voto, pero Apolo no acepta, pues prefiere el amor de Climene antes que el perdón de los dioses. Mientras tanto, ante la llegada inminente de Admeto y el intento de Apolo de ausentarse para desenojar a los dioses, Fitón trata de ocultar a Climene. Admeto inquiere a Fitón por la identidad del amante de su hija; Clicie trata de explicárselo, pero al hacerlo enmudece, lo mismo le pasa a Céfiro, y a Flora. La primera se convierte en flor, Céfiro en viento y los demás desaparecen. Fitón reconoce que los hados se han salido «con sus influjos severos», que es reconocer a Admeto que se han cumplido los crueles hados. En el drama El hijo del sol, Faetón, que ya se anuncia aquí, veremos escénicamente representada la realidad de ese cumplimiento.

Lo que primero sorprende de esta obra son las reminiscencias al unísono tan destacadas de La vida es sueño y El galán fantasma. De la primera tiene la función dramática y el valor de los hados, el encierro del protagonista por su padre para escapar de esos hados, y el fatalismo, del que escapa Segismundo pero no Climene, pues la historia a la que Calderón se somete no se lo permite. De drama tiene el no acabar la obra felizmente, pues como dice al final Sátiro:

$$
\begin{aligned}
& \text { Si a esta perdonáis los yerros, } \\
& \text { por la novedad siquiera, } \\
& \text { dama y galán dividiendo, } \\
& \text { de acabar ella en divorcio, } \\
& \text { cuando otras en casamiento }^{42} \text {. }
\end{aligned}
$$

Y el pronóstico pesimista que ya anuncia ese final, y que veremos en el Faetón realizado. Pero la obra se mueve con mucha soltura en el ambiente de la comedia: entradas y salidas de personajes, ocultamientos, relaciones cruzadas, etc. Finalmente de fábula tiene el aspecto general de la historia mitológica, la presencia de una divinidad, Apolo, y sobre todo los aspec-

\footnotetext{
${ }^{41}$ Ibid., p. 1902, a

42 Ibíd., p. 1908, a.
} 
tos fantásticos: la aparición de un palacio maravilloso y la conversión, o metamorfosis al estilo ovidiano, de Clicie en flor y Céfiro en viento (congruente con su nombre). Según Baltasar de Vitoria, Clicie, abandonada por su amante Apolo, dejó de beber y comer hasta convertirse en la flor llamada heliotropo ${ }^{43}$, a lo que alude también Calderón cuando dice que se transformó «en pajiza flor del sol,/que va sus rayos siguiendo» ${ }^{44}$; es, naturalmente, la flor que nosotros llamamos girasol.

Respecto a los puntos de contacto con El galán fantasma, casi todos guardan relación con la importancia que se da a la mina como medio de comunicación de los amantes. Hay, no obstante un cierto fatalismo también en ese medio de la mina, que en El galán fantasma está construida para la venganza de un agravio relacionado con el padre de Julia por antagonistas familiares, y aquí, fatalmente, es el lugar donde parece predestinado Apolo a caer junto a Climene para que se cumpla el horóscopo. En ambas obras este conducto es decisivo vehículo de sorprendentes y emocionados encuentros y apariciones, pues por ejemplo, el primer momento de hallazgo entre ambos amantes tiene lugar de forma absolutamente sorprendente, saliendo en el primer caso Astolfo de las entrañas de la tierra ante la aterrorizada Julia, quien no tarda en desmayarse, mientras en el segundo caso Apolo aparece sorprendentemente ante Climene quien se defiende de lo que cree una profanación tratando de disparar su arco contra él. También la mina es origen de considerables confusiones, pues su construcción afecta a otros que la conocen o descubren. Amigos, como Carlos en El galán fantasma, o amantes como Céfiro de Flora en Apolo y Climene. Finalmente invita a huidas precipitadas, como la que protagoniza Astolfo del Duque, o la que realiza Apolo llevándose a Climene por el Erídano, huyendo de Admeto. Las dos obras tienen muchos puntos en común, pero todos ellos participan del mismo motivo: el factor de la mina es el que fusiona los parentescos entre ellas. No obstante en Apolo y Climene la mina involucra a todos los personajes de una manera más explícita y directa aun.

Respecto a la función semántica de la mina en esta obra es múltiple y muy rica. Al ser Apolo un dios del que se presumen anteriores amores, como su vehículo de acceso a Climene es la mina, y como la mina es conocida por otros personajes que la utilizan para sus amores furtivos, como ocurre con Céfiro y Flora ${ }^{45}$, nada tiene de extraño que se crucen en el camino unos y otros, proporcionando diversos sentidos y valores de significado a esos encuentros y al ámbito de los mismos. Así, para un chusco

\footnotetext{
${ }^{43}$ Baltasar DE Vitoria, Primera Parte del Teatro de los Dioses de la Gentilidad, 1646, p. 667.

${ }^{44}$ Apolo y Climene, ed. cit., p. 1908, a.

${ }^{45}$ Para los amores de Céfiro y Flora vid. la mencionada obra de Baltasar de Vitoria, que conoció Calderón y que pudo influir en él (Ed. cit., p. 645 y ss.)
} 
como Sátiro, podrá ser metáfora de «ratonera», como ocurre cuando Céfiro se esconde creyendo que Flora le es infiel con Apolo:

CÉFIRO Traiciones suyas y desdichas mías
¿qué no harán? Aunque el ver que satisfecha
desvanecer intenta mi sospecha,
diciéndome que vuelva
al jardín, y a salir no me resuelva
hasta que la gruta abra, me ha puesto
en duda de que hay misterio en esto.
Y pues la noche ya vistiendo baja
al cadáver del sol negra mortaja,
mientras que yo a la mina
me arrojo, tú esconderte determina
en las ramas, dejándotela abierta,
siempre, Sátiro, alerta. (Abre la sima.)
Y si el hombre viniere,
déjale entrar primero, sea quien fuere,
y ciérrala después; que una vez dentro,
verá por donde ha de huir, si yo lo encuentro.
¿Posible es que no ves que esa quimera
en metáfora está de ratonera... ${ }^{46}$

Mientras que para Climene la mina, como vimos, es una obra de amor («amor ingeniero»). Y como tal es un verdadero camino de liberación, principalmente de la prisión injusta a que la ha conducido su cruel padre de la mano del hado fatal. Hay en Calderón un verdadero camino de libertad en la elección de la acción de amar (más que del amor, propiamente dicho), aunque ese camino sea duro y suponga pagar una cuota muy dura en responsabilidad. Aun así el que los personajes pongan a prueba su propia seguridad nos muestra que para el dramaturgo esta pasión posee una fuerza de transformación total, y por tanto una reivindicación de la persona en tanto que sujeto amante y capaz de amar.

Por otro lado, si la mina es lógicamente lugar de secreto y de ocultamiento, al sospechar Flora que Céfiro ha enseñado a Climene el secreto de ella y está en conocimiento de muchos más, es lógico que piense que «Ya es/el secreto a voces éste» ${ }^{47}$. Y Climene, sabedora de todo esto, dirá:

Climene Mucho me temo que ellos hagan la mina, y yo la reviente ${ }^{48}$.

Quizá presagiando el oscuro final de ella misma.

\footnotetext{
${ }^{46}$ Apolo y Climene, ed. cit., p. 1883, b.

47 Ibíd., p. 1885, b.

${ }^{48}$ Ibíd.
} 
La mina para la mujer aquí puede ser lugar de despeñamiento no sólo físico sino también moral. Recordemos cómo Flora, cuando Céfiro huye por la mina temiendo que lo reconozca Climene decía:

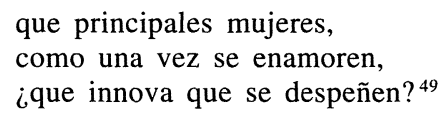

Y esto verdaderamente vale para ella pero también simbólicamente para Climene. No se puede andar por minas impunemente, parecen decirnos, sin que se corra el peligro de despeñarse, o lo que es lo mismo: situarse en el laberinto de la pasión supone ponerse al borde de arder en su fuego y quemarse. Por eso, con simbolismo cierto, decía Tisbea al verse deshonrada por Don Juan en el Burlador de Tirso:

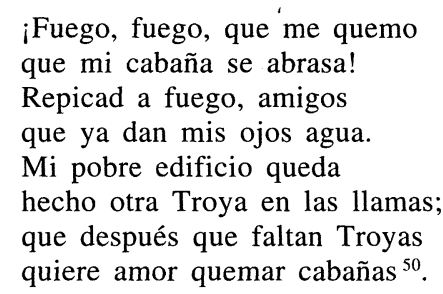

Lo mismo hará Climene cuando se haga de noche y vea asaltado su recinto secreto por el desconocido Apolo:

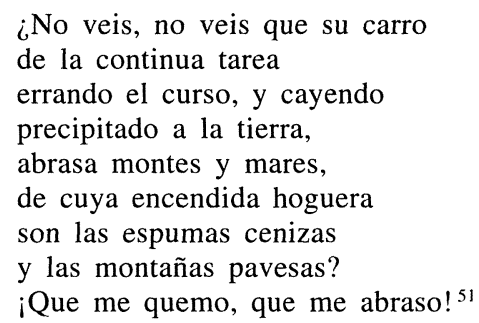

En donde, prefigurando el desastre de Faetón, revela también los estragos del fuego que acompaña a Apolo o el Sol, estragos que la alcanzan igualmente a ella. La mina así será el lugar culpable, que se debe ocultar al responsable del honor femenino, en este caso al propio padre, y cuando éste la va a castigar, la llegada de Apolo (el Sol, la luz, el fuego, la pasión, el amor) la retorna a salvar llevándola en sus brazos. Por eso el pro-

\footnotetext{
${ }^{49}$ Apolo y Climene, ed. cit., p. 1886, a.

${ }^{50}$ TiRso DE Molina, El burlador de Sevilla, ed. de Joaquín Casalduero, Madrid, Cátedra, 1977, p. 65, vv. 985-992.

${ }^{51}$ Apolo y Climene, ed. cit., p. 1869, a.
} 
pio Apolo, abrasado en su mismo fuego verá con sorpresa cómo una mina construida para ser vehículo de agua se convierte en camino de fuego:

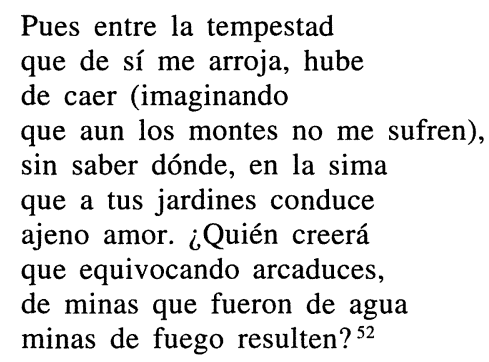

Así pues la mina tendrá en esta obra un sentido polivalente, desde el laberinto de oscuridad y encierro hasta el lugar de salida y de encuentro amoroso. Y será también ambivalente, como el fuego: rescata de la oscuridad pero puede quemar su luz. La obra que promete ser un enredo amable, se complica y acaba siendo un enigma de reflexión, una solución sin solución, una unión amorosa que acaba en divorcio, y una terrible premonición de desgracias futuras. Es la obra más compleja y difícil que Calderón escribió sobre el motivo central de la mina, porque en ella el laberinto que es siempre el camino que se elige para actuar no tiene un único sentido, ni se dirige a una sola dirección.

En resumen, podríamos decir, después de este recorrido, que los caminos tortuosos de Calderón, como éste, se abren a múltiples significaciones, a incesantes sugerencias, que van de lo cómico a lo trágico, de la condena a la salvación, de la prisión a la libertad y de ésta a la responsabilidad o al destino. La mina es un camino oscuro, como la vida, cuando se sale de ella no sabemos con seguridad qué nos espera.

\footnotetext{
52 Ibíd., p. 1902, a.
} 


\title{
RESUMEN
}

El camino de la mina, vehículo de emociones en Calderón, por Enrique Rull.

Calderón utiliza varios recursos escénicos para establecer determinadas situaciones dramáticas en sus obras. El que se estudia aquí se refiere a la función de la mina, que posee valores polisémicos muy notables, los cuales van desde los que le sirven para establecer un ámbito guerrero, religioso, amoroso de carácter real, hasta la utilización de este motivo con carácter metafórico de la pasión amorosa o como verdadero laberinto de amor que incluye incluso una mitologización trascendente de la misma. Todo ello le sirve para configurar en sus obras una acción trepidante, misteriosa, en la que se mezcla lo cómico con lo trágico, y en donde lo inesperado cobra un valor no sólo de esencia dramática sino también de vivencia existencial acerca del destino de la vida.

Palabras clave: Temas en la literatura, obra literaria de Calderón, teatro de la Edad de Oro.

\begin{abstract}
Calderon uses some scenic devices to stablish certain dramatic situations in the plays The studied here is related to the function of the mine, which possessed important polisemic values. Not only it is used for stablishing a belic religious or a reat loving environement but also to use this motif with the metaphoric value of passion or as a true laberinto of love, includying trascendental mitological symbols. Everything together is aimed to create a very fast and mysterious activity mixing both comic and tragic effects in which the nonexpected becomes not only dramatical essence but also a personal experience about destinity and life.
\end{abstract}

Key words: Literary themes, Calderon's works, golden age's theatre. 